\title{
FOOD SOUVENIRS FROM BALI - WHAT MATTERS FOR TOURISTS FROM JAKARTA?
}

\author{
Diena Mutiara Lemy ${ }^{*}$, Debbie Darmawan ${ }^{2}$ and Julio Putra $\mathrm{Tj}^{3}$ \\ ${ }^{123}$ School of Hospitality and Tourism, Universitas Pelita Harapan, Indonesia \\ diena.lemy@uph.edu
}

\begin{abstract}
Bali is one of the popular destinations in Indonesia. It is not only popular for the international tourists, but also for domestic tourist. One large segment of Bali domestic tourist is from Jakarta. This segment like to buy food souvenir from Bali, even though the food do not presenting Balinese local food.

The purpose of this research is to determine the degree of influence from brand image, brand awareness and dimension of food souvenirs from Bali towards buying decisions of Tourist from Jakarta when they are in Bali. Usually, product with good brand image and good brand awareness could attract people to buy the products.

This research uses descriptive quantitative approach, where the data is collected through questionnaire and observations. To analyze the data, multiple linear regression analysis using SPSS program was applied. The result will determine if the brand awareness and brand image of food souvenirs really influence buying decision of tourist from Jakarta or not. The benefit of this research is expected that it will be a beneficial insight for the tourism industry in Bali in making a strategy for increasing tourist expenditure, from the food souvenirs sector.
\end{abstract}

Keywords: Food Souvenirs, Bali, Brand Image, Brand Awareness, Buying Decision, Tourism.

\section{INTRODUCTION}

The island of Bali as a tourist destination has indeed been known for a long time by domestic and foreign tourists. Bali offers value high on natural, cultural, and spiritual elements inherent. Attractiveness tourism in Bali has also won the hearts of tourists through various kinds of dances, culinary diversity, and cultural ritual celebrations held regularly every year. Bali offers potential products tours that include cultural tourism, nature tourism, marine tourism and city tourism. This tropical climate in Bali is located in the central part of Indonesia and occupies an area of 5.636,66 hectares or about 0,29\% of total area of Indonesia (Suryana, 2012).

Bali is also famous for its diverse ethnic souvenirs, many of which sell souvenirs of various Balinese souvenirs on the beach and the center of souvenirs. There are many motivations to buy souvenirs, mean roles souvenirs as gifts (Kim \& Littrell, 2001), as a sign (Gordon, 2004), and as a reminder (Litirell et al., 1994; Swanson, 2004). Role souvenirs as gifts include the role of reintegration and desacralization (Gordon, 2004) and gift-giving and self-gifting behavior. Dobbs et 
al, (2012) stated that urban residents often spend their money to fulfil a lifestyle that is classified as luxurious, by traveling to expensive places and using hotel facilities that have high prices, as well as consumption power or the nature of a large shopping including souvenirs.

However, there are also some popular snacks that are favored by tourists. These popular snacks then become food souvenirs that are mainly sought by the tourists, especially domestic tourists from Jakarta. Some of the popular snacks are: pie, milk pie, banana cake, and layered cake. This is a unique phenomenon because these popular snacks are not representing Balinese local food.

Based on the explanation, there is something that can be hypothesized, that made food souvenirs from Bali desirable by the tourists even though they are not representing Bali is because they have good brand image, brand awareness and contain the food souvenir dimensions for tourists. To confirm this, this paper is trying to investigate the influence of brand image, brand awareness and dimensions of food souvenir of four food souvenirs from Bali towards the Jakarta's tourists buying decision.

The dimensions of food souvenir are: the local taste, non-perishable, the size, easy to bring (pass the flight baggage check), the variations, affordable, the smell is tolerable, not easily broken, familiarity and the health benefit (Altintzoglou, Heide, \& Borch, 2016). According to Pfoertsch \& Kotler (2010), Brand Awareness is the ability of a consumer to identify a brand (both know and remember) with a certain detail (symbols, sounds, images, etc.) in making a purchase. Brand awareness does not require a consumer to remember the name of a brand, but only to remember the small details of a brand, for example in the form of symbols, sounds, colors and so on. Brand awareness plays a role in influencing consumer purchasing decisions. Consumers will choose a product that is better known than buying a product that they have never known at all. In addition, this research uses the dimension of food souvenirs (quality, taste, etc.) as factors influencing the tourists to buy food souvenirs.

On the first stage of this research, 25 people from Jakarta who have gone to Bali before were asked about some food souvenirs from Bali (there are four brands being asked). $92 \%$ of them confirm that they know and have experienced buy at least one of the snacks as souvenir. This proves that The food souvenir I bought has a good brand image and brand awareness so that it can survive even in expansion outside the region and among the tourists from Jakarta.

The information from this research can be a beneficial insight for the tourism industry in Bali in making a strategy for increasing tourist expenditure, from the souvenirs sector.

From the above explanation, there are three hypotheses to be tested:

$\mathrm{H}_{1}$ : There is a relationship between brand image and purchase decision.

$\mathrm{H}_{2}$ : There is a relationship between brand awareness and purchase decision.

$\mathrm{H}_{3}$ : There is a relationship between food souvenir dimension and purchase decision. 


\section{METHODOLOGY}

The type of investigation in this research is correlation research, which is in line with the purpose of this research that is to identify the influence of brand image, brand awareness and food souvenir dimensions on Jakarta's tourists purchase decision. The data collection method is using questionnaire and observation, to get the primary data. Based on the characteristic of data used, this research is crosssectional research because data used are taken at a given time.

The sampling method is non-probability purposive sampling. The unit analysis of this research is individuals which are tourists from Jakarta, who have experienced buying at least one of the four brands of the food souvenirs being investigated. The number of questionnaires being distributed were 238. After the questionnaires checking, only 200 that were considered valid. The four brands are not mentioned here for the ethical reasons.

In the study there is one dependent variable, namely the purchasing decision of tourists to buy food souvenir $(\mathrm{Y})$ and three independent variables namely brand image (X1), brand awareness (X2), and food souvenir dimension (X3). Data collected is done weighting using the Likert scale with six alternative answers namely Very Agree (VA), Agree (A), Slightly Agree (SA), Slightly Disagree (SD), Disagree (D) and Very Disagree (VD). The data result was analyzed using regression analysis with SPSS 22.

TABLE 1

Questionnaire Items

\begin{tabular}{|c|l|}
\hline \multicolumn{1}{|c|}{ Items } & \multicolumn{1}{|c|}{ Source } \\
\hline $\begin{array}{l}\text { A.Motivation of Souvenir Purchase } \\
\text { 1. When travelling, I buy souvenirs to be given to others }\end{array}$ & $\begin{array}{l}\text { (Kim \& Littrell, } \\
2001)\end{array}$ \\
\hline 2. I buy souvenir as a reminder if the destination I visited & $\begin{array}{l}\text { (Zauberman, Ratner, } \\
\text { \& Kim, 2009) }\end{array}$ \\
\hline 3. I buy souvenir as a proof that I visited certain place & $\begin{array}{l}\text { (Gordon, 2004) } \\
\text { (MacCannell, 1989). }\end{array}$ \\
\hline $\begin{array}{l}\text { B. Brand Image } \\
\text { 1. The food souvenir I bought is a unique food at where I } \\
\text { live }\end{array}$ & $\begin{array}{l}\text { (Suhartanto, Chen, } \\
\text { Mohi, \& Sosianika, } \\
\text { 2. In my opinion, the food souvenir I bought is quite } \\
\text { aesthetic when served }\end{array}$ \\
\hline 3. I think the food souvenir I bought is an iconic Balinese \\
souvenir \\
4. I think the food souvenir I bought represents the taste of \\
$\begin{array}{l}\text { Bali } \\
\text { 5. In my opinion, the packaging of the food souvenir I } \\
\text { bought is interesting }\end{array}$ & $\begin{array}{l}\text { (Altintzoglou et al., } \\
\text { 2016) }\end{array}$ \\
\hline
\end{tabular}




\begin{tabular}{|c|c|}
\hline Items & Source \\
\hline $\begin{array}{l}\text { C.Brand Awareness } \\
\text { 1. I am familiar with the food souvenir I bought } \\
\text { 2. I remember the food souvenir I bought more than any } \\
\text { other food souvenirs } \\
\text { 3. If I am asked to mention Balinese souvenir, the food } \\
\text { souvenir I bought is the first think that pop in my mind } \\
\text { 4. I know what exactly what the food souvenir I bought is } \\
\text { 5. I can immediately recognize the food souvenir I } \\
\text { bought just by looking at the variant }\end{array}$ & $\begin{array}{l}\text { (Durianto, 2004) } \\
\text { (Rochaety \& } \\
\text { Tresnati, 2007) }\end{array}$ \\
\hline $\begin{array}{l}\text { 6. My relatives/friends suggest me to buy the food } \\
\text { souvenir I bought }\end{array}$ & $\begin{array}{l}\text { (Altintzoglou et al., } \\
\text { 2016) }\end{array}$ \\
\hline $\begin{array}{l}\text { D.Food Souvenir Dimension } \\
\text { 1. I chose to buy local food as souvenir. } \\
\text { 2. I consider the food souvenir I bought as a non- } \\
\text { perishable souvenir } \\
\text { 3. In my opinion, the size of the food souvenir I bought is } \\
\text { just right (not too small/big) } \\
\text { 4. My items pass baggage check when I bring the food } \\
\text { souvenir I bought } \\
\text { 5. I satisfied with the variations of the food souvenir I } \\
\text { bought. } \\
\text { 6. The food souvenir I bought is affordable } \\
\text { 7. I consider buying the food souvenir I bought because it } \\
\text { has no smell in baggage } \\
\text { 8. I bought the food souvenir because It is not easily } \\
\text { broken } \\
\text { 9. I decided to buy the food souvenir I bought because I } \\
\text { have ever tried it before } \\
\text { 10. I believe that there is health benefit in the food souvenir } \\
\text { I bought }\end{array}$ & $\begin{array}{l}\text { (Altintzoglou et al., } \\
\text { 2016) }\end{array}$ \\
\hline $\begin{array}{l}\text { E. Purchase Decision } \\
\text { 1. I bought the food souvenir because of the diversity of } \\
\text { its products } \\
\text { 2. I bought the food souvenir because of the image } \\
\text { 3. I bought the food souvenir because of its popularity } \\
\text { 4. I bought the food souvenir because the shop was in a } \\
\text { strategic place } \\
\text { 5. I bought a lot of the food souvenir I bought } \\
\text { 6. When buying the food souvenir, it is easy to pay in cash } \\
\text { 7. When buying the food souvenir, it is easy to pay using } \\
\text { credit card }\end{array}$ & $\begin{array}{l}\text { (Julita, Lemy, \& } \\
\text { Ingkadijaja, 2018) }\end{array}$ \\
\hline
\end{tabular}

\section{RESULTS AND DISCUSSION}

The majority of the respondents' frequency of visiting Bali were 1-3 times in this last 3 years are 164 respondents which means $82 \%$ out of 200 respondents. 
The second one is 10 percent which is 20 respondents out of 200 respondent who have visited Bali 4-6 times in these 3 years. The last one is more than 6 times of visiting Bali in this 3 is only 16 people / 8\% out of 200 respondents.

FIGURE 1

Frequency of Visiting Bali

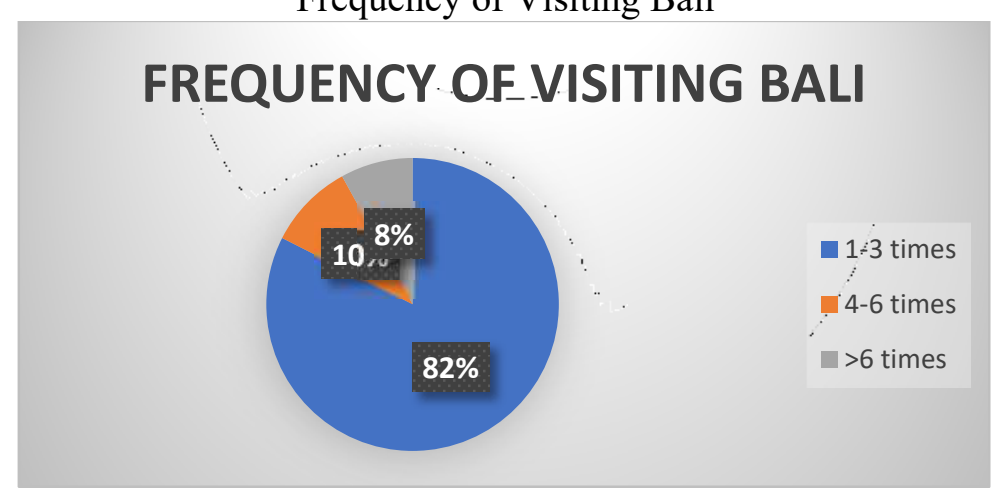

From the first question, which is "Motivation for souvenir purchases [When travelling, I buy souvenirs to be given to others]". It is identified that 49 percent of the 200 respondents, which numbers 98 respondents agree that "Motivation of souvenir purchases [When travelling, I buy souvenirs to be given to others]".

The second question, "Motivation of souvenir purchases [ I buy souvenir as a reminder if the destination I visited]". It shows that 49 percent which is 98 people out of the total respondents agree that there is some motivation "I buy souvenir as a reminder if the destination I visited".

For the third question, "Motivation of souvenir purchases [I buy souvenir as a proof that I visited certain place]". It can be identified that 31 percent of the respondents, which is 62 respondents agree that based on their experienced as a consumer, they "I buy souvenir as a proof that I visited certain place".

Overall, from this variable (motivation of buying souvenir), the most influencing factor out of these three questions is the first question (when travelling, I buy souvenirs to be given to others) which means that people tend to buy souvenirs to be given to others.

For the variable Perceived Ease Of Use, the first question which is "Brand Image [The food souvenir I bought is a unique food at where I live]". The majority of the respondents consisting of 75 people which makes up 37.5 percent of the whole respondents agree that the effect of "Brand Image [The food souvenir I bought is a unique food at where I live]".

In the second question "Brand Image [In my opinion, the food souvenir I bought from Bali is quite aesthetic when served]", it is identified that 44.5 percent which is 89 respondents agree that it affect them to buy "The food souvenir I bought in Bali is quite aesthetic when served".

The third question "Brand Image [I consider The food souvenir I bought in Bali as one of Bali's iconic souvenirs]" shows that the majority of the respondents which is 37 percent and 74 number of respondents agree that The food souvenir I bought in Bali as one of Bali's iconic souvenirs. 
The fourth question "Brand Image [I think the food souvenir I bought represents Balinese flavors as souvenirs]" concludes that the majority of the respondents consisting of 67 people and is 33.5 percent of the total respondents agree that The food souvenir they bought represents Balinese flavors as souvenirs. The last question "Brand Image [In my opinion, the food souvenir I bought in Bali packaging is interesting]" concludes that the majority of the respondents consisting of 68 people and is 34 percent of the total respondents slightly agree that the food souvenir they bought Bali packaging is interesting. Overall, from this variable (brand image), the most influencing factor from this 5 questions is the first question (The food souvenir I bought is a unique food at where I live) which means that people think that the food souvenir they bought is a unique food.

The third variable above shows the frequencies about Brand Awareness. The first question which is "Brand awareness [I am familiar with the food souvenir I bought]" shows that the majority of respondents consisting of 72 people which makes up to 36 percent of the whole respondents (200 people) agree that they are familiar with the food souvenir they bought.

The second question "Brand awareness [I remember the food souvenir I bought more than any other food souvenir]" has the total of 85 respondents which is 42.5 percent of the total respondents agree that they can remember the food souvenir they bought than other types of food souvenirs.

The third question "Brand awareness [If I am asked to mention Balinese souvenir, The food souvenir I bought is the first think pop in my mind]" has 69 people which is 34.5 percent of the whole respondents agree that when they asked to mention Bali souvenirs, The food souvenir they bought is the thing that pop in my mind.

The fourth question "Brand awareness [I know exactly what the food souvenir I bought is]" has 78 people which is 39 percent of the whole respondents agree that when they know exactly what he food souvenir they bought is.

The fifth question "Brand awareness [I can immediately recognize the food souvenir I bought just by looking at the variant]" has 72 people which is 36 percent of the whole respondents slightly agree that they can recognize The food souvenir I bought just by looking the model variant.

The last question "Brand awareness [My relatives/friends suggest me to buy the food souvenir I bought]" has 79 people which is 39.5 percent of the whole respondents agree that There are relatives or friends who recommend buying the food souvenir they bought.

Overall, from this variable (brand awareness), the most influencing factor from these six questions is the first question (I am familiar with the food souvenir I bought) which means that a lot of people are familiar with the food souvenir they bought.

The fourth variable above shows the frequencies about Food Souvenir Dimension. The first question which is "Food Souvenir Dimension [I chose to buy local food as souvenir]" shows that the majority of respondents consisting of 69 people which makes up to 34.5 percent of the whole respondents agree that they prefer buying local food as souvenirs.

The second question "Food Souvenir Dimension [I consider the food souvenir I bought as a non-perishable souvenir]" has the total of 82 respondents which is 41 percent of the total respondents agree that the food souvenirs they bought were not easily perish 
The third question "Food Souvenirs Dimension [In my opinion, the size of the food of souvenirs I bought is just right (not too small/big)]" has 69 people which is 34.5 percent of the whole respondents agree that the size of the food souvenir they bought is just right (not too big/small).

The fourth question "Food Souvenirs Dimension [My items pass baggage check when I bring the food souvenirs I bought]" has 78 respondent which is 39 percent of the whole respondents agree that the food souvenirs they bought were easily passes luggage when carrying on the board.

The fifth question "Food Souvenir Dimension [I am satisfied with the variations of the food souvenirs they bought]" has 81 respondent which is 40.5 percent of the whole respondents agree that they are satisfied with the variant of the food souvenirs they bought.

The sixth question "Food Souvenir Dimension [The food souvenir I bought is affordable]" has 71 respondent which is 35.5 percent of the whole respondents agree that the price of the food souvenirs they bought were affordable.

The seventh question "Food Souvenir Dimension [I consider buying the food souvenir I bought because it has no smell in baggage]" has 73 respondent which is 36.5 percent of the whole respondent agree that they buying the food souvenirs because it does not smell in baggage.

The eight question "Food Souvenir Dimension [I bought the food souvenir because It is not easily broken]" has 68 respondent which is 34 percent of the whole respondents slightly agree that they buy the food souvenirs because it is not easily broken.

The ninth question "Food Souvenir Dimension [I decided to buy the food souvenir I bought because I never tried it before]" has 67 respondent which is 33.5 percent of the whole respondent agree that they bought the food souvenirs because they never try it before.

Last question "Food Souvenirs Dimension [I believe that there is health benefit in the food souvenirs they bought]" has 51 respondents which is 25.5 percent of the whole respondents slightly agree that the food souvenirs they bought have benefits for health.

Overall, from this variable (food souvenir dimension), the most influencing factor from these ten questions is the first question (I consider the food souvenirs I bought as a non-perishable souvenir) which means that the food souvenirs they bought is not perish easily.

The last variable is purchase decision. In the first question "Purchase Decision [I bought the food souvenirs because of the many diversity of its products]" has 60 respondents which is 30 percent from the total respondents slightly agree that they bought the food souvenirs because of many diversity of the products.

The second question which is "Purchase Decision [I bought the food souvenirs because of the image]" has 38 percent or 76 respondents from the total respondents agree that they bought the food souvenirs because of the image.

The third question "Purchase Decision[I bought the food souvenirs because of its popularity]" has 36.5 percent from the total respondents, which is 73 respondents agree that they bought the food souvenirs because of its popularity.

The fourth question "Purchase Decision [I bought the food souvenirs because the shop is in a strategic place]" has 36 percent from the total respondents, 
which is 72 respondents slightly agree that they buy the food souvenirs because the shop is in a strategic place.

The fifth question "Purchase Decision [I bought a lot of food souvenirs]" has 30 percent from the total respondents, which is 60 respondents slightly agree that they bought a lot of food souvenirs.

The sixth question "Purchase Decision [when buying the food souvenirs, it is easy to pay in cash]" has 34.5 percent from the total respondents, which is 69 respondents agree that they bought the food souvenirs because it is easy to pay in cash.

The last question "Purchase Decision [when buying the food souvenirs, it's easy to pay by credit card]" has 31.5 percent from the total respondents, which is 63 respondents both slightly agree and agree that when buying the food souvenirs, it is easy by credit card.

Overall, from this variable (purchase decision), the most influencing factor from these seven questions is the third question (I bought the food souvenirs because of its popularity) which means that people tend to buy souvenirs that is popular.

The first hypotheses is there is a relationship between brand image and purchase decision. Based on the results of statistical tests, it is known the coefficient of the brand image is 0.160 which means that the higher the brand image perception, the higher the purchase decision perception. The test results show that the GIS value is 0.00650 .05 (alpha 5\%) then it is concluded statistically at the 95 percent confidence level there is a positive influence of brand image on the purchase decision. Therefore, the hypotheses 1 is accepted.

The next hypotheses is there is a relationship between brand awareness and purchase decision. Based on the results of statistical tests, it is known the coefficient of the brand image is 0.160 which means that the higher the brand image perception, the higher the purchase decision perception. The test results show that the GIS value is 0.00650 .05 (alpha 5\%) then it is concluded statistically at the 95 percent confidence level there is a positive influence of brand image on the purchase decision.

Finally, the third hypotheses is there is a relationship between food souvenir dimension and purchase decision. Based on the results of statistical tests, it is known that the coefficient of food souvenir dimension is 0.501 which means the higher the perception of food souvenir dimension, the higher the purchase decision perception. The test results showed a p-value of 0.00050 .05 (alpha 5\%), so it was concluded statistically at the 95 percent confidence level there was a positive influence of food souvenir dimension on the purchase decision.

From the result of multiple linear regression that have been conducted, it can be concluded that: first, there is positive and significant influence between brand image with purchase decision; second, there is positive and significant influence between brand awareness with purchase decision; there is positive and significant influence between food souvenir dimension with purchase decision.

This research imply that tourist from Jakarta buy the food souvenirs from Bali because of the good brand image and high level of brand awareness that influence tourist from Jakarta.

In doing the research, researcher faced limitations that are expected not to happen in the future research. The limitation is the respondent were only tourist 
from Jakarta. This may affect the interpretation and generalization of this research. The result of the research might be different and more generalized if the populations are expanded to more tourist from different cities

\section{REFERENCES}

Altintzoglou, T., Heide, M., \& Borch, T. (2016). Food souvenirs: buying behaviour of tourists in Norway. British Food Journal, 118(1), 119-131. https://doi.org/10.1108/BFJ-05-2015-0190

Dobbs, R., Remes, J., Manyika, J., Roxburgh, C., Smit, S., \& Schaer, F. (2012). Urban world: Cities and The Rise of The Consuming Class. McKinsey \& Company.

Durianto, D. (2004). Strategi Menaklukkan Pasar Melalui Riset Ekuitas dan Perilaku Merek. Jakarta: PT. Gramedia Pustaka Utama.

Gordon, B. (2004). The souvenir: Message of the extraordinary. Journal of Popular Culture, 20, 135.

Julita, Lemy, D. M., \& Ingkadijaja, R. (2018). The Influence Of Brand Performance And Service Quality Towards Guest Decision To Stay At Four-Star Hotel In Tangerang, (November), 8-10.

Kim, S., \& Littrell, M. A. (2001). Souvenir buying intentions for self versus others. Annals of Tourism Research, 28(3), 638-657. https://doi.org/10.1016/S0160-7383(00)00064-5

Litirell, M. A., Baizerman, S., Kean, R., Gahring, S., Niemeyer, S., Reilly, R., \& Stout, J. (1994). Souvenirs and Tourism Styles. Journal of Travel Research, 33(1), 3-11. https://doi.org/10.1177/004728759403300101

MacCannell, D. (1989). The Tourist: A New Theory of the Leisure Class. Schocken Books.

Pfoertsch, W., \& Kotler, P. T. (2010). Ingredient Branding: Making The Invisible Visible. Springer Science \& Business Media.

Rochaety, E., \& Tresnati, L. R. (2007). Metodologi Penelitian Bisnis dengan Aplikasi SPSS. Jakarta: Mitra Wacana Media.

Suhartanto, D., Chen, B. T., Mohi, Z., \& Sosianika, A. (2018). Exploring loyalty to specialty foods among tourists and residents. British Food Journal, 120(5), 1120-1131. https://doi.org/10.1108/BFJ-09-2017-0485

Suryana, D. (2012). Bali: Bali dan Sekitarnya. CreateSpace Independent Publishing Platform

Swanson, K. K. (2004). Tourists' and retailers' perceptions of souvenirs. Journal of Vacation Marketing, 10(4), 363-377. https://doi.org/10.1177/135676670401000407

Zauberman, G., Ratner, R. K., \& Kim, B. K. (2009). Memories as Assets: Strategic Memory Protection in Choice over Time. Journal of Consumer Research, 35(5), 715-728. https://doi.org/10.1086/592943 